\title{
IDENTIFICATION AND CHARACTERISTICS OF THE LEADERS OF THE EUROPEAN MARKET OF LOGISTIC SERVICES
}

\section{REGINA DEMIANIUK, PhD}

Faculty of Economic and Legal Sciences,

Siedlce University of Natural Sciences and Humanities, Poland

\section{KEYWORDS: LOGISTIC SERVICE, EUROPEAN TFL, SNCF}

1. The value of logistic market in European countries

Logistics is gaining importance, both within Europe and on a global scale. The global logistic industry is estimated at 5,4 trillion euro or $13.8 \%$ of the global GDP. On average, logistic costs account for $10-15 \%$ of the financial cost of finished product. In the European Union (EU) logistics share of GDP reaches $20-25 \%$. The share of transport spending in the final product in the European Union is 11\%. [http://eurlex.europa.eu/legal-content/PL/TXT/?uri=URISERV:I24456]. Value of logistic market in Europe in 2012 and 2014 is presented in Table 1.

Table 1. European leader countries in terms of logistic market value in 2012 and 2014 (in billion Euro)

\begin{tabular}{|l|l|l|l|l|}
\hline $\begin{array}{l}\text { Specification of } \\
\text { market }\end{array}$ & $\begin{array}{l}\text { Position in } \\
\text { the ranking } \\
\text { in } \mathbf{2 0 1 2}\end{array}$ & $\begin{array}{l}\text { in } \mathbf{2 0 1 2} \text { in } \\
\text { billion Euro }\end{array}$ & $\begin{array}{l}\text { Position in } \\
\text { the ranking } \\
\text { in 2014 }\end{array}$ & $\begin{array}{l}\text { in 2014 } \\
\text { in billion } \\
\text { Euro }\end{array}$ \\
\hline Germany & 1 & 228.0 & 1 & 235.0 \\
\hline France & 2 & 126.3 & 2 & 124.7 \\
\hline Great Britain & 3 & 99.2 & 3 & 95.6 \\
\hline Italy & 4 & 75.2 & 5 & 71.0 \\
\hline Spain & 5 & 70.6 & 4 & 71.9 \\
\hline The Netherlands & 6 & 47.6 & 6 & 56.4 \\
\hline Poland & 7 & 45.0 & 7 & 53.4 \\
\hline Norway & 8 & 30.1 & 9 & 31.6 \\
\hline Sweden & 9 & 29.7 & 10 & 27.6 \\
\hline Belgium & 10 & 29.7 & 8 & 32.4 \\
\hline
\end{tabular}

Source: Compiled on the basis of: Top 100 in European Transport and Logistic Services 2013/2014, Fraunhofer SCS, Nuremberg,http://www.scs.fraunhofer.de/content/ $\mathrm{dam} / \mathrm{scs} / \mathrm{de} /$ dokumente/studien/TOP100_Executive_Summary_20132014.pdf;Top 100 in European Transport and Logistic Services 2015/2016, Fraunhofer Center for Applied Research on Supply Chain Services SCS, Nuremberg, https:// www.scs.fraunhofer.de/content/dam/scs/de/dokumente/ studien/Top 100 EU 2015 Executive Summary.pdf, (Date of access: May 20, 2017).

As show in Table 1, Germany is the European leader of logistics. The value of logistic market in Germany was estimated at 228 billion Euro in 2012. Overall, the value of the European market (for 30 countries) was assessed at 930 billion Euro in "Top 100 in European Transport and Logistic Services 2013/2014" report. The group of the next 10 countries in 2012 included: Finland, where the value of logistic market amounts to 22.3 bn Euro, Switzerland - 22.1 bn Euro, Austria - 18.8 bn Euro, Greece 16.7 bn Euro, Denmark- 14.9 bn Euro, the Czech Republic - 9.8 bn Euro, Romania - 6.9 bn Euro, Portugal - 6.9 bn Euro, Irleand - 6.4 bn Euro, Hungary - 4.2 bn Euro. On the other hand, the value of logistic market in Luxembourg amounted to 3.3 bn Euro, Slovakia - 3.0 bn Euro, Latvia- 2.6 bn Euro, Bulgaria - 2.5 bn Euro, Estonia - 2.2 bn Euro, Croatia - 2.1 bn Euro, Slovenia - 1.8 bn Euro, Cyprus 0.7 bn Euro, Malta - 0.3 bn Euro.

In 2014, the value of German logistic market was estimated at 235 billion Euro, and the value of the European market was assessed at 960 billion Euro in "Top 100 in European Transport and Logistic Services 2015/2016" report. The top ten countries in 2014 included: France, where the value of logistic market amounts to 124.7 bn Euro, Great Britain - 95.6 bn Euro, Spain - 71.9 bn Euro, Italy - 71.0 bn Euro, the Netherlands - 56.4 bn Euro, Poland - 53.4 bn Euro, Belgium - 32.4 bn Euro, Norway - 31.6 bn Euro, Sweden - 27.6 bn Euro. The logistic market value in other countries in 2014 was as follows: Switzerland - 22 bn Euro, Finland -20.8 bn Euro, Greece - 19.3 bn Euro, Austria - 19.1 bn Euro, Denmark - 14.9 bn Euro, Czech Republic - 10.7 bn Euro, Romania - 7.9 bn Euro, Portugal - 7.7 bn Euro, Ireland 6.4 bn Euro, Hungary - 4.9 bn Euro, Slovakia - 3.4 bn Euro, Luxembourg - 3.1 bn Euro, Bulgaria - 3.1 bn Euro, Latvia - 2.9 bn Euro, Lithuania - 2.6 bn Euro, Estonia - 2.2 bn Euro, Croatia - 2.1 bn Euro, Slovenia - 2.1 bn Euro, Cyprus - 0.7 bn Euro, Malta - 0.3 bn Euro.

2. Leaders of the European TFL (transport, forwarding, logistics) market

Outsourcing of logistic activities made by enterprises caused the development of logistic operators that are named as 3PL [See more: Demianiuk, R. (2015)]. Contract logistics is understood as cooperation, which is the subject of the contract and consists in transferring the logistic functions to the external contractor by the company. The logistic operator can take steps towards an integration of activities and advanced cooperation between 3PL operators and their partners in order to manage the entire supply chain system. A logistic service provider will move to another level of involvement fourth-party logistics provider (4PL). The management of the entire supply chain in the conjunction with e-business allows to separate the highest level of operator's involvement $-5 \mathrm{PL}$ [See more: Fechner, I., Szyszka, G. (ed.), (2012), p. 21 - 26].

TFL market is developed by logistics, transport, forwarding, warehouse, delivery and postal companies which contribute to cargo operations within the framework 
of contract logistics [Fechner, I., Szyszka, G. (ed.), (2014), p. 27]. The most important link in the European and world TFL market are logistic operators who are currently focusing on delivering complex and comprehensive logistic service to customers as well as providing a broad range of logistics, additional and ancillary services. Logistic operators service more and more branches. Providing logistic services on a level that satisfy customers allows the logistic operator to obtain rational benefits. However, increased competition impels logistic market participants to search for innovative solutions to meet the growing needs of customers.

Logistic operators leading in logistic service, have well qualified staff in a number of countries in the world and on different continents. Companies compile service portfolio adjusted to expectations of customers who are often from different industries. A service is complex and it covers all stages of the supply chain, from supply via production and distribution to after-sales service. The operators have a big warehouse area in different locations around the world, which considerably enhances delivering of goods in time. They actively invest in extension of logistic infrastructure. Action in accordance with "7R" principle is a basis of success of the operators. The operators continuously conduct market research and they often extend the variety of offerred services and design their own service coming up with proposals for the customer. The operators apply many e-logistic solutions. On-line transport orders can be submitted online in the country, both in export and import. They allow you to check the status of your shipment by monitoring both domestic and international shipments, allowing you to check the estimated shipping time. For example, DB Schenker allows to perform an on-line check of gas emission that is made by different means of transport, and therefore the company allows for environmental impact assessment that can be made by the customer. The choice depends on the customer. Most of the customers are large and medium-sized, domestic and international, production and commercial companies having many suppliers and receivers both in the country and around the world. The customers are interested in highly professional and complex logistic service. Companies which are leaders on the logistic market ensure a smooth movement of goods and flow of information in the service of global supply chains.

Top 10 operators of global logistic market that were included in the report "Top 100 in European Transport and Logistic Services" in 2012 and in 2014 are entities included in Table 2.

It can be easily noticed that the leader is a German company - DHL, which represents courier, express and parcel industry (CEP). The top ten companies in 2012 were European companies. In 2014, there were 5 European companies among 10 leader companies, 4 American and 1 Japanese company. The same report "Top 100 in European Transport and Logistic Services" lists the following ten European leaders of TFL market in 2012 and 2014. These are companies included in Table 3.

Turnover of Deutsche Post DHL, the leader of TFL market in Europe, decreased from 27.8 bn Euro obtained in 2012 to 25.8 bn Euro dited in 2014. Also turnover of worldwide leader of ocean cargo - Maersk A/S, shrank in Europe from 15.4 bn Euro to 14.8 bn Euro, including 2.6 bn Euro turnover from Damco International B.V. (part of Maersk) that majors

Table 2. Leaders of the global logistic market in 2012 and 2014

\begin{tabular}{|c|c|c|c|c|c|c|c|}
\hline $\begin{array}{l}\text { Position } \\
\text { in the } \\
\text { ranking in } \\
2012\end{array}$ & $\begin{array}{l}\text { Leaders of global } \\
\text { market in } 2012\end{array}$ & Home country & $\begin{array}{l}\text { Logistics } \\
\text { revenue } \\
\text { worldwide } \\
2012 \text { in bn } \\
\text { Euro } \\
\end{array}$ & $\begin{array}{l}\text { Position in } \\
\text { the ranking } \\
\text { in } 2014\end{array}$ & $\begin{array}{l}\text { Leaders of global } \\
\text { market in } 2014\end{array}$ & Home country & $\begin{array}{l}\text { Turnover } \\
\text { in } 2014 \text { in } \\
\text { bn Euro }\end{array}$ \\
\hline 1 & Deutsche Post DHL & Germany & 46.3 & 1 & Deutsche Post DHL & Germany & 48.0 \\
\hline 2 & UPS Inc. & USA & 41.0 & 2 & UPS Inc. & USA & 47.9 \\
\hline 3 & China Railway Group & China & 40.0 & 3 & FedEx Corp. & USA & 43.2 \\
\hline 4 & FedEx Corp. & USA & 34.3 & 4 & Maersk A/S & Denmark & 29.7 \\
\hline 5 & Maersk A/S & Denmark & 29.7 & 5 & $\begin{array}{l}\text { DB Mobility Logistics } \\
\text { AG }\end{array}$ & Germany & 19.8 \\
\hline 6 & JSC Russian Railway & Russia & 28.0 & 6 & Union Pacific Railroad & USA & 18.6 \\
\hline 7 & $\begin{array}{l}\text { DB Mobility Logistics } \\
\text { AG }\end{array}$ & Germany & 19.9 & 7 & BNSF Railway Company & USA & 18.4 \\
\hline 8 & $\begin{array}{l}\text { Kühne+Nagel } \\
\text { International AG }\end{array}$ & Switzerland & 17.2 & 8 & Russian Railways & Russia & 16.9 \\
\hline 9 & CMA-CGM SA & France & 15.9 & 9 & $\begin{array}{l}\text { Nippon Yusen K.K (NYK } \\
\text { Group) } \\
\end{array}$ & Japan & 16.0 \\
\hline \multirow[t]{2}{*}{10} & BNSF Railway & USA & 15.3 & 10 & $\begin{array}{l}\text { Kühne+Nagel } \\
\text { International AG }\end{array}$ & Switzerland & 14.5 \\
\hline & Total & - & 287.6 & & Total & - & 273.0 \\
\hline
\end{tabular}

Source: Compiled on the basis of: Top 100 in European Transport and Logistic Services 2013/2014, Fraunhofer SCS, Nuremberg, http:// www.scs.fraunhofer.de/content/dam/scs/de/dokumente/studien/TOP100_Executive_Summary_20132014.pdf; Top 100 in European Transport and Logistic Services 2015/2016, Fraunhofer Center for Applied Research on Supply Chain Services SCS, Nuremberg, https:// www.scs.fraunhofer.de/content/dam/scs/de/dokumente/studien/Top 100 EU 2015 Executive Summary.pdf, (Date of access: May 20, 2017). 
Table 3. Leaders of European logistic market in 2012 and 2014

\begin{tabular}{|l|l|l|l|l|l|l|l|}
\hline $\begin{array}{l}\text { Position in } \\
\text { the ranking } \\
\text { in } \mathbf{2 0 1 2}\end{array}$ & $\begin{array}{l}\text { Leaders of } \\
\text { European market } \\
\text { in } \mathbf{2 0 1 2}\end{array}$ & $\begin{array}{l}\text { Home } \\
\text { country }\end{array}$ & $\begin{array}{l}\text { logistics } \\
\text { revenue in } \\
\text { Europe 2012 in } \\
\text { bn Euro }\end{array}$ & $\begin{array}{l}\text { Position in } \\
\text { the ranking } \\
\text { in 2014 }\end{array}$ & $\begin{array}{l}\text { Leaders of European } \\
\text { market in 2014 }\end{array}$ & $\begin{array}{l}\text { Home } \\
\text { country }\end{array}$ & $\begin{array}{l}\text { Turnover in } \\
\mathbf{2 0 1 4} \text { in bn } \\
\text { Euro }\end{array}$ \\
\hline 1 & Deutsche Post DHL & Germany & 27.8 & 1 & Deutsche Post DHL & Germany & 25.8 \\
\hline 2 & Maersk A/S & Denmark & 15.4 & 2 & DB Mobility Logistics AG & Germany & 15.1 \\
\hline 3 & $\begin{array}{l}\text { DB Mobility } \\
\text { Logistics AG }\end{array}$ & Germany & 14.8 & 3 & Maersk A/S & Denmark & 14.8 \\
\hline 4 & $\begin{array}{l}\text { Kühne+Nagel } \\
\text { InternationalAG }\end{array}$ & Switzerland & 10.3 & 4 & $\begin{array}{l}\text { Kühne+Nagel } \\
\text { nnternational AG }\end{array}$ & Switzerland & 11.7 \\
\hline 5 & SNCF SA & France & 9.5 & 5 & SNCF SA & France & 9.0 \\
\hline 6 & CMA-CGM SA & France & 8.0 & 6 & La Poste (Group) & France & 7.1 \\
\hline 7 & La Poste & France & 6.1 & 7 & CMA-CGM SA & France & 6.9 \\
\hline 8 & UPS Europe NV & Belgium & 5.7 & 8 & $\begin{array}{l}\text { The Royal Mail Holdings } \\
\text { PlC. }\end{array}$ & Great Britain & 6.6 \\
\hline 9 & DSV A/S & Denmark & 5.1 & 9 & UPS Europe NV & Belgium & 6.0 \\
\hline 10 & TNT Express & $\begin{array}{l}\text { the } \\
\text { Netherlands }\end{array}$ & 4.7 & 10 & DSV A/S & Denmark & 5.4 \\
\hline & Total & - & 107.4 & & Total & - & 108.7 \\
\hline
\end{tabular}

Source: Compiled on the basis of: Top 100 in European Transport and Logistic Services 2013/2014,Fraunhofer SCS, Nuremberg, http://www. scs.fraunhofer.de/content/dam/scs/de/dokumente/studien/TOP100_Executive_Summary_20132014.pdf;Top 100 in European Transport and Logistic Services 2015/2016, Fraunhofer Center for Applied Research on Supply Chain Services SCS, Nuremberg, https://www.scs. fraunhofer.de/content/dam/scs/de/dokumente/studien/Top 100 EU 2015 Executive Summary.pdf, (Date of access: May 20, 2017).

in ocean carrier. On the other hand, turnover of DB Mobility Logistics AG increased from 14.8 bn Euro in 2012 to 15.1 bn Euro in 2014. In 2014, turnover of DB Schenker Logistics (part of DB Mobility Logistics AG) accounted to 10.2 bn Euro, whereas turnover of DB Schenker Rail (part of DB Mobility Logistics AG) totalled 4.8 bn Euro. Turnover of La Poste also increased from 6.1 bn Euro to 7.1 bn Euro, including turnover of GeoPost (part of La Poste) that amounted to 4.9 bn Euro in 2014. Turnover of Dutch company - General Logistics Systems B.V. (GLS) - part of Royal Mail, amounted to 2.1 bn Euro.

Among the leaders of TFL sector on the European market in 2014, there were three companies from France, two from Germany and two from Denmark. There were also companies from Switzerland, Belgium and Great Britain. In the first ten positions, the report presented CEP services - the area of activity of analyzed business entities, in great detail. TNT Express which held tenth position in the ranking in 2012, has dropped to sixteenth position in 2014. The further ten places in the ranking were occupied by the following TFL market entities:

1. Dachser SE (Germany),

2. XPO Logistics Inc. (formerly Norbert Dentressangle SA),

3. Rhenus SE \& Co. KG (Germany),

4. Mediterranean Shipping Company Holding SA (MSC) (Switzerland),

5. Gefco SA (France),

6. TNT Express (the Netherlands)

7. CEVA Group Plc, (Great Britain),

8. Volkswagen Konzernlogistik $\mathrm{GmbH} \& \mathrm{Co.OHG}$ (Germany),

9. STEF SA (France),

10. Bollore Holding SA (France).

Contract logistics accounts for $41 \%$ of the European logistic market volume, Warehousing and Terminal - 11\%, Ocean Cargo - 9\%, General Truckload (FTL) - 9\%, Specialized
Transportation - 8\%, Bulk Logistics - 8\%, CEP-7\%, Groupage/ LTL $-5 \%$, Air Freight - 2\%.

There is not any Polish company from TFL sector in the top twenty of the above-mentioned ranking but many international logistic operators from the above list of TFL leaders are on the Polish TFL market. Global operators had a significant impact on the improvement in the level of competitiveness of Polish logistic market. Services and standards that were previously new and unknown in Poland became available. Having analyzed interests of particular activity profiles in the revenues of logistic companies operating on the Polish market, it may be concluded that logistic companies most often focus on providing forwarding trade and transport services. Another significant profile of activity are warehousing services [Fechner, I., Szyszka, G. (ed.), (2012), p. 150-153]. An increase in the number of logistic companies providing integrated logistic service has been observed. These companies offer services, from national and international transport, through warehouse economy, to breaking bulk of goods and distribution. The leading logistic operators are characterized by increase in the number and quality of the services being offered.

On the basis of ranking published by daily „Rzeczpospolita" in "LTS" supplement ${ }^{1}$ that was devoted to TFL companies according to revenues from core TFL sales in 2011 and 2012, distribution of companies depending on the revenue shows that the Polish market is divided into big and smaller companies. The big companies provide services as logistic operator and they hold foreign and mixed capital, whereas the smaller companies with mainly Polish capital fall within the ambit of forwarding trade and road transport area [See more: Demianiuk, R., Telakowiec, K., (2013), p. 60].

1 Ranking ok. TFL companies, prepared under the direction of Prof. Halina Brdulak from Warsaw School of Economics, published in daily Rzeczpospolita", „Gazeta Prawna" (Daily Legal Newspaper). 
The following table presents the ranking of TFL companies according to the value of revenues from TFL activity in 2015.

Table 4. Ten leading companies in Poland according to the amount of revenues from TFL activity for the year 2015

\begin{tabular}{|l|l|l|l|}
\hline $\begin{array}{l}\text { Position } \\
\text { in the } \\
\text { ranking }\end{array}$ & Company & $\begin{array}{l}\text { Revenues } \\
\text { from TFL } \\
\text { activity in } \\
\mathbf{2 0 1 5} \text { (in } \\
\text { thou. PLN) }\end{array}$ & $\begin{array}{l}\text { Capital/ Country } \\
\text { of origin of foreign } \\
\text { capital }\end{array}$ \\
\hline 1 & Grupa Raben & 2144406 & $\begin{array}{l}\text { foreign/100\% the } \\
\text { Netherlands }\end{array}$ \\
\hline 2 & Schenker Sp. z o.o. & 1478340 & Polish \\
\hline 3 & DPD Polska Sp. z o.o. & 1163591 & $\begin{array}{l}\text { foreign/100\% } \\
\text { France }\end{array}$ \\
\hline 4 & LOTOS Kolej Sp. z o.o. & 669438 & Polish \\
\hline 5 & $\begin{array}{l}\text { ROHLIG SUUS Logistics } \\
\text { S.A. }\end{array}$ & 601059 & Polish \\
\hline 6 & PEKAES & 555489 & $\begin{array}{l}\text { foreign/63\% } \\
\text { Luxembourg }\end{array}$ \\
\hline 7 & DSV & 544033 & $\begin{array}{l}\text { foreign/ 100\% } \\
\text { Denmark }\end{array}$ \\
\hline 8 & Kühne+Nagel & 502852 & $\begin{array}{l}\text { foreign/100\% } \\
\text { Austria }\end{array}$ \\
\hline 9 & Jas-Fbg S.A. & 462822 & Polish \\
\hline 10 & $\begin{array}{l}\text { Panalpina Polska Sp. z } \\
\text { o.o. }\end{array}$ & 373946 & $\begin{array}{l}\text { foreign/100\% } \\
\text { Switzerland }\end{array}$ \\
\hline
\end{tabular}

Source: 21st edition of ranking of TFL companies, Dziennik Gazeta Prawna (Daily Legal Newspaper), vol. 122 (4269)/2016.

DHL Global Forwarding LLC (limited liability company) took 11th place in the above-mentioned ranking in Poland. In most of TFL companies the share of trading turnover in the trade is significant. Therefore, an adjustment to changes in that sector such as development of on-line sales through retail chains is becoming a priority. E-commerce becomes an area of active operating for TFL companies that works in Poland. Polish market of logistic services is in a dynamic development phase. Internationalization of business activity has a significant impact on the development of logistic services' sector. As the economy develops, there is a growing demand for logistic services and logistics outsourcing becomes increasingly important.

\section{Characteristics of the European leading TFL} companies and their service offer

The top ten entities of the European logistic market in 2014 included: Deutsche Post DHL (Group), DB Mobility Logistics $A G$, Maersk $A / S$, Kuehne+Nagel International $A G$, SNCF SA, La Poste (Group), CMA-CGM SA, The Royal Mail Holdings Plc, UPS Europe NV, DSV A/S. The leading company is Deutsche Post DHL. E-consumer market is dynamically developing in Europe and throughout the world. E-consumers attach great importance to the price, convenience of shopping and quality of service. Courier companies are highly popular and they are expanding their offer. CEP trade as a part of TFL sector has been dynamically developing. CEP services can be realized by postal operators, courier companies, as well as by logistic operators and transport companies. CEP is a trade that is undergoing the biggest growth among TFL companies thanks to the development of e-commerce sector.

Deutsche Post DHL is an international company, a world leader of postal and logistic services which runs business activity in more than 220 countries and employs around 510 thousand workers around the world. Deutsche Post DHL is one of 10 largest employers in the world. In 2016, Deutsche Post DHL Group earned revenues of more than 57 bn Euro [Deutsche Post DHL (Group), Taken from: http://www.dpdhl. com/en/about_us/at_a_glance.html,(10.06.2017)]. Deutsche Post DHL includes Deutsche Post - postal services in Germany and mail parcel delivery worldwide, as well as DHL - the logistic company for the world. Deutsche Post is an expert in dialogue marketing, press distribution and also in solutions concerning corporate communication. DHL company is wellknown and solid brand in logistics. Currently, DHL employs over 350 thousand people. DHL consist of: DHL Express, DHL Parcel, DHL eCommerce, DHL Global Forwarding, DHL Fracht i DHL Supply Chain [Company portrait, DHL, Taken from: http://www.dhl.com/en/about_us/company_portrait.html].

$\mathrm{DHL}$ provides a wide range of logistic services, for example, international express transport, domestic and international parcel delivery, solutions related to road, railway, maritime, and air transport within online trade, supply chain management. The company focuses on the servicing the needs of biological sciences and health care, high technology, energetic, motorization, production. On the website, DHL sets out in detail solutions offered for the customers as a part of logistic service [Logistics, DHL Global, Taken from: http:// www.dhl.com/en/logistics.html]:

- Freight transportation²,

- Warehousing and Distribution,

- Supply Chain Solutions,

- Lead Logistics Partner (LLP),

- Temperature Controlled Logistics,

- Green Logistics Solutions,

- Customs, Security \& Insurance,

- Industry Sector Solutions (Aerospace and Aviation, Automotive, Chemical, Consumer, Energy, Fashion, Engineering and Manufacturing, Life sciences and Healthcare, Retail, Technology),

- Customer Resource Area.

2 Thus, for example, DHL company implemented the following solutions as a part of air transport service: AIR PRIORITY, AIR CONNECT,AIR ECONOMY, AIR CHARTER, AIR THERMONET, AIRFREIGHT PLUS, LIFECONEX, SAMEDAY JETLINE, SAMEDAY SPEEDLINE, AIE COMBINED. Solutions as a part of Road and Rail Freight service for European, African and Middle East regions are as follows: Consolidated Groupage, Palletized and Non Palletized Cargo (LTL); Direct Full Truck Loads (FTL) and Part Loads (PTL); Rail and Intermodal Services Non Standard Cargo. Solutions as a part of Road and Rail Freight service for Asia - Pacific region are as follows: ASIACONNECT - Consolidated Groupage (LTL), ASIALINE - Direct Part and Full Track Loads (PTL and FTL), ASIANET - Dedicated Full Track Load Network, Domestic Transportation Services within AsiaPacific. The operator has also a broad offer within logistics service with the use of maritime transport: OCEAN DIRECT, OCEAN CONNECT LCL, OCEAN CONTAINER MANAGEMENT, OCEAN SPECIAL, OCEAN ASSEMBLY, OCEAN CHARTER. Other service options to consider: FLEXITANKS, OCEAN SECURE, OCEAN THERMONET, OCEAN VIEW. Besides, DHL suggests the following logistics solutions within freight transportation: AIRFREIGHT PLUS - Day Definite intra-European and intra-Asia, SEAIR - Multimodal Air and Ocean Freight, DOOR-TO-MORE- Direct Distribution Solutions, FREIGHT EURONET - European Managed Ground Transport, MANAGED GROUND TRANSPORT. Within Intermodal \& Multimodal Transport services, the following are provided: DHL INTERMODAL, DHL RAILLINE, DHL RAIL CONNECT, DHL SEAIR, DHL DOOR-TO MORE. See more: Freight transportation, http://www.dhl.com/en/logistics/freight_ transportation.html. 
Comprehensive range of services through land transport is rendered with the use of over 180 road terminals in more than 50 countries and assistance of customs experts at over 275 offices. The company provides door-to-door services handling more than 3500 trips per week with full tracking service. As a result, the company can deliver a commodity to any place in the world by using various modes of transport according to the client's expectations. DHL provides also services within warehouse and distribution logistics. As Lead Logistics Partner (LLP), it can efficiently manage and improve the entire supply chains through optimization of costs, reduction of wastage and change control management. The customers often have special requirements for a specific storage of goods or transport temperature. Of course, DHL implemented many solutions to help meet the above-mentioned requirements. The company emphasizes professional logistic service, including all safety standards, norms and environmental challenges. DHL seeks to build up long term relationships in collaboration with the customers.

The second place in the ranking of leading logistic companies in Europe was taken by DB Mobility Logistics AG. The group companies perform passenger and freight services; operate transport infrastructure caring of its proper condition and development; coordinate the network of railway, road, maritime and air connections. The group comprises of DB Bahn (comprehensive passenger service), DB Netze (transport infrastructure, IT, energy transmission, etc.), DB Schenker (two divisions Logistics and Rail, comprehensive transport-logistic solutions).

DB Group works in over 130 countries throughout the world and hires more than 300 thousand employees, including around 195 thousand people working in Germany [DB, Taken from: http://www.deutschebahn.com/en/group/ ataglance/facts_figures.html, (Date of access: June 12, 2017)]. The company makes every effort to ensure that its products will be delivered to European and global markets in well-preserved form and on the right time, thanks to an integrated and comprehensive logistic service. In Germany, DB carries 5.5 bn passengers and transports 596 thousand tons of freight by train every day. Railway is the main subject of DB's activity. DB owns 33.3 thousand kilometers of modern railway network and it handles more than 40 thousand trains every day. The number of train stations amounts to 5681 . DB Group carries almost 12 billion passengers across Europe (including Germany) by its own trains or buses. Every day, over 1.8 bn customers travel by DB buses in Germany [See more: Key performance figures, http://www.deutschebahn. com/en/group/ataglance/facts_figures.html].

DB Schenker, a specialist in transport and logistics, connects the main economic regions in over 40 European countries. The services offered by the company cover: land solutions, complex railway logistics, intermodal service, air and ocean solutions, warehouse logistics, comprehensive customs service, service of special transports including carriage of overgauge goods and ADR (Carriage of Dangerous Goods by Road) as well as logistics of global sports events. In 2016, the company generated revenues of 15128 bn Euro (see Table 5). DB Schenker holds the first position in the European land transport and it hires about 24 thousand people in 730 locations. DB Schenker provides its clients with optimized logistic services for break-bulk cargoes, partial consignments and full load consignments. The company operates around 32 thousand of regular services for break-bulk cargoes every week. Annullay, DB Schenker operates about 1200 charter flights that connects logistic hubs on all continents. Logistic operators can use a warehouse area of 8 million square meters in almost 50 countries on different continents. DB Schenker transports annually around 300 billion tons of cargo by train and carries out land transportation of almost 100 billion of consignments within the European network. The company transports over 1.1 million tons of air freight and over 2.0 million TEU of ocean freight within its global network.

Table 5. The key figures on DB Schenker for the year 2016

\begin{tabular}{|l|l|}
\hline Specification & Numbers \\
\hline Revnues (million Euro) & 15128 \\
\hline $\begin{array}{l}\text { Worldwide employees (permanent employees at 31 } \\
\text { December 2015) }\end{array}$ & 68388 \\
\hline Locations around the world & 2000 \\
\hline $\begin{array}{l}\text { Shipments in the European road transport (in } \\
\text { thousand) }\end{array}$ & 99,638 \\
\hline Volume of air freight (export) (in thousand tonnes) & 1,179 \\
\hline Volume of ocean freight (export) (in thousand TEU) & 2,006 \\
\hline
\end{tabular}

Source: DB Shenker, http://www.dbschenker.pl/log-pl-pl/start/ o-firmie/dbschenker_worldwide.html, (Date of access: June 12, 2017).

In 2015, DB group noticed incomes (adjusted) that totaled 40.5 bn Euro as demonstrated below, in Table 6. DB has a strong interest in strengthening market position in order to maintain the competitiveness.

Table 6. Revenues, profit and capital expenditures of DB Group

\begin{tabular}{|l|l|}
\hline Specification & Data \\
\hline Revenues and profit, Revenues adjusted, million Euro & 40.576 \\
\hline EBITDA adjusted, $\mathrm{mln}$ & 4.797 \\
\hline EBIT adjusted, $\mathrm{mln}$ & 1.946 \\
\hline Capital expenditures, Gross capital expenditures, $\mathrm{mln}$ & 9.510 \\
\hline Net capital expenditures, mln & 3.320 \\
\hline
\end{tabular}

Source: Key financial figures, http://www.deutschebahn.com/ en/group/ataglance/facts_figures.html, (Date of access June 6, 2017).

The third position in Top 100 Europe 2014 ranking took Maersk A/S company which provides integrated transport and logistics services. The company is a global leader in transport of intermodal containers. A.P. Moller - Maersk Group (Transport and Logistics sector consists of Maersk Line, APM Terminals, Damco, Svitzer and Maersk Container Industry; and Energy sector consists of Maersk Oil, Maersk Drilling, Maersk Supply Service and Maersk Tankers) hires 88000 employees in 130 countries worldwide [A.P. Moller - Maersk, Taken from: http://www.maersk.com/en/themaersk-group/about-us, (Date of access: June 14, 2017)]. 
Maersk A/S company efficiently supports global supply chains and facilitates international and global exchange for the customers.

Maersk Line is the biggest European and worldwide container shipping company. Maersk Liner also includes Safmarine, Seago Line, SeaLand and MCC. The company has a fleet that consists of 639 ships sailing on varied world trade routes. Maersk Line hires 31858 employees. APM Terminals is a leading global port and cargo inland services provider to drive global commerce. The company publishes on its website that the its global network comprises of 189 ports and inland facilities in 61 countries [APM Terminals, Taken from: http://www.apmterminals.com/]. APM Terminals hires 22615 employees. The company has the main office in the Hague in the Netherlands. It cooperates actively with shipping lines, importers/exporters, governments and with big companies having strong business position. This cooperation aims in providing solutions in the movement of goods that could meet the customers' requirements. On the other hand, Damco company is a world-famous supplier of forwarding trade services. The company focuses on the supply chain management towards optimization and affirmation of long-term competitiveness for particular links in the supply chain. Damco hires 11292 employees. Another entity of Maersk A/S group specializing in Transport and Logistics sector is Svitzer. It is a company with a long tradition which has provided safety and support at sea. Svitzer is wellknown in Europe and worldwide as a company that tows vessels and reacts in emergency situations. The company hires 2870 employees and has a fleet that consists of over 500 vessels. Maersk Container Industry $(\mathrm{MCl})$ designs and manufactures refrigerated containers, dry containers and the Star Cool refrigeration machine which are actively used in intermodal transport, including shipping lines, international fruit concerns, leasing companies. The $\mathrm{MCl}^{\prime}$ s residence, centers of research and development as well as engineering centers are located in Denmark, whereas production facilities are in China and Chile.

The next European leader in logistics is Kuehne + Nagel International AG which offers full range of logistic services in contract logistics and integrated logistics. This company is specialized in different kinds of forwarding trade: road, rail, shipping and air. Kuehne + Nagel International AG is so called on stop shopping provider of logistic services. The operator's service offer is tailored to the individual needs and expectations of the customers. Kuehne + Nagel hires over 70000 employees in 100 countries in the world (more than 1300 offices). The company actively cooperates with the best ocean carriers. Kuehne+Nagel International is certified for Global Cargo iQ Phase 2. The company focuses on air freight forwarding to develop the innovative management concept for cargo transport. Kuehne + Nagle has an established network of warehouse and distribution facilities in the world. The company is marked by „pan-European overland transportation capabilities, including dedicated and individual delivery services and close partnerships with best-in-class carriers". Kuehne + Nagel provides logistic services for many industrial sectors: aerospace, automotive, FMCG, High Tech,
Industrials, Oil ang Gas Logistics, Pharma and Healthcare, Retail [Kuehne + Nagel, Taken from: https://www.kn-portal. com/about_us/about_us/, (Date of Access: June 6, 2017)].

Leading Transport and Logistics company in France, SNCF SA, ranked the fifth position in the ranking of European logistic leaders (the $20^{\text {th }}$ positions in the world). The structure of that company includes: SNCF Réseau, SNCF Voyageurs, KEOLIS, SNCF Logistics, SNCF Immobilier. SNCF Réseau - a French railway carrier manages, develops and monitors the French rail network - 30000 kilometres of railway line, including 2000 kilometres of high speed lines. The company hires 52 thousand employees. SNCF Voyageurs facilitates travelling providing common mobile solutions delivered by business units - Transilien, TER, Intercités, Voyages SNCF and Gares \& Connexions. Vojages-sncf.com the top on-line travel agency in France. On the other hand, Keolis company is a big operator of collective transport in France which runs business activity also on other markets (it is presented in 15 countries in the world). It operates buses, metro system, streetcar lines, trains, car parks, bikes, car-sharing, ride-sharing, ferries and river shuttles. This is a global leader in automated metros and light rail. The company hires 50 thousand employees, including $40 \%$ outside the France. SNCF Logistics is a professional full-service logistic partner. It has 120 sales offices in 120 countries. Its organizational structure includes four business lines which are listed below [SNCF Group, Taken from: http:// www.sncf.com/en/meet-sncf/public-service-company]:

- GEODIS - is specializing in the following sectors of activity: Supply Chain Optimization, Freight Forwarding, Contract Logistics, Distribution \& Express and Road Transport;

- TFMM - operates freight transportation by rail transport and multimodal transportation;

- STVA - European specialist in finished-vehicle logistics and preferred partner for many leading car manufacturers and rental companies. STVA is in the possession of flee that consists of 3600 wagons and 835 light-vehicle carriers. It also has 42 vehicle holding areas and preparation centers in Europe.

- ERMEWA - manages specialized wagons and tank containers for industrial clients.

SNCF Immobilier optimally manages SNCF properties. It sells land and rail properties that can no longer be used in the rail system, to various public or private entities for urban development. SNCF Immobilier manages real estate with building space of 12 million sqm and 20000 hectares of land. SNCF Immobilier also manages around 100000 residential units, whereas $90 \%$ of them is social housing.

La Poste (Group) - the sixth position in the ranking of TFL leaders in Europe. The company is a leader in postal services on the French market and one of the biggest postal operator. The parcel sector generates high revenues in the company. For example, DPD courier company acting with a great success in Poland is a part of GeoPost holding owned by French post La Poste [La Poste Group improves results thanks to Poland, daily „Rzeczpospolita”, Taken from: http:// 
www.rp.pl/Biznes/307319846-Grupa-La-Poste-poprawiawyniki-dzieki-Polsce.html\#ap-1, (Date of Access: June 16, 2017)]. The essential objective of DPD's business as an international courier network for GeoPost holding is to ensure consistent customer service standards in all countries where the company operates. DPD group delivers 4 million consignments worldwide every day. DPD provides standard (DPD Classic) and express (e.g. DPD City, DPD Sameday, City Express) national services as well as standard (DPD Classic) and express (DPD Express and DPD Guarantee) international service. In Great Britain there is also a French holding GeoPost that operates as a part of LaPoste. In 2016, GeoPost noted revenues of 6.2 bn Euro [See more: DPD, https://www.dpd. com.pl/klienci-biznesowi/O-DPD/O-firmie/Historia]. La Poste has five divisions in its structure [La Poste, Taken from: http:// legroupe.laposte.fr/profil/le-groupe-en-bref/l-essentiel]:

1. Post \& Parcel services: core business, copartnerships: Mediapost, Viapost Services, Asendia (joint venture with Swiss Post), SOGEC;

2. GeoPost: Chronopost, DPD, Seur, Interlink Express, Pickup Services;

3. Postal bank (La Banque Postale): banking, asset management, insurances;

4. La Poste network (local chain, banking multi-activity): La Poste Mobile, branch of La Poste in cooperation with mobile SFR operator;

5. Digitisation (on-line customer service, development of La Poste e-commerce, documents): Docapost, Start'inPost, Mediapost Communication.

CMA-CGM SA company takes the seventh place in the ranking of European logistic leaders and eleventh place in the global ranking, being the third Worldwide Shipping Group at the same time. CMA-CGM has a huge fleet and it also offers solutions in inland transport. The company has a very extensive international network: ports (ports of call) in 160 countries, over 755 agencies and over 29000 employees. Activities of CMA-CGM: shipping, intermodal and logistics.

The company is a leader of French maritime shipping industry. CMA CGM and its subsidiaries offer more than 170 lines calling 400 ports. With five hubs located in Malta, Tangier, Khor Fakkan, Port Kelang and Kingston, the Group serves major and regional trades. The company has a modern fleet of 445 vessels. The CMA CGM fleet counts three of the largest container vessels (16 020 TEUs): the CMA CGM Marco Polo, the CMA CGM Alexander Von Humboldt and the CMA CGM Jules Verne. These will be complemented soon by six ships of 18000 TEUs [CMA-CGM, Taken from: https://www. cma-cgm.com/the-group/about-us/corporate-movie, (Date of Access: July 17, 2017)]. CMA CGM offers solutions - dry containers for dry goods or refrigerated containers for goods. Also offer solutions for shipping oversized cargo (Break Bulk, OOG) and goods requiring special precautions. CMA CGM LOG offers logistic services for international transport. The company provides highly professional multimodal transport solutions using different modes of transport: rail, barge, lorry, plane. A lot of companies which are industry giants entrust management of their supply chains in the direction of their optimization to CMA AGM LOG, which offers a wide range of logistic offer.

The Royal Mail Holdings Plc, a British postal undertaking, took eight position in the analyzed ranking of the European TFL leaders. Royal Mail provides "one-price-goes-anywhere" services for 29 million addresses across the UK six days a week. Royal Mail Group Limited is the principal trading entity of Royal Mail Plc. The organizational structure of Royal Mail consists of: Royal Mail Investments Limited, Royal Mail Estates Limited, Romec Limited, General Logistics Systems B.V. (GLS) [Royal Mail, Taken from: http://www. royalmailgroup.com/about-us/who-we-are, (Date of Access: June 17, 2017)]. The courier company GLS has one of the most extensive distribution network in Europe that covers 41 countries, including Poland. It also operates 7 states of the USA. The GLS Group has 62 central sorting offices, about 26 thousand vehicles, over 1 thousand agencies. It serves over 240 thousand customers and hires 17 thousand people [GLS Group, Taken from: https://gls-group.eu/PL/pl/fakty-iliczby\#]. GLS delivered 508 bn consignments in 2016/2017. Parcel delivery in Poland takes place on the next working day, whereas in Europe it takes 48 to 96 hours. The company enables the customers to track parcel deliveries. There is a low percentage of parcels' damage.

UPS Europe NV (central Office in Belgium) took ninth position in the European logistic ranking. UPS (United Parcel Service with central office in USA) is the biggest company in the world that is involved in the delivery of consignments. It is one of the global leading providers of special transport and logistic services. UPS hires over 434 thousand people in the world (350 000 in the USA, 45000 in Europe). In 2014, the number of delivered consignments amounted to 4.6 billion parcels and documents. The service area covers 220 countries and territories in the world (over 50 countries and territories in Europe). The delivery fleet in Europe has over 9 thousand cars and trucks. Daily number of flights across Europe is 151 and 142 in the case of intercontinental flights [UPS Europa, Taken from: https://www.ups.com/pl/pl/about/facts/europe.page?, (Date of Access: June 18, 2017)].

The UPS structure is as follows: UPS Air Cargo, UPS Capital Corporation, Customer Solutions (UPS Problem Solvers), UPS Mail Innovations, The UPS Store, Inc., UPS Freight, UPS Supply Chain Solutions. UPS Services by type: Shipping, Tracking, Billing, International trade, Contract Logistics, Integrating UPS Technology. UPS services by size: Individual Shipper, Small Business, Mid-to-Large Businesses, Customized Solutions. UPS services by industry: Healthcare, Consumer Goods and Retail, High Tech, Industrial Manufacturing and Distribution, Automotive, Aerospace and Defense [UPS, Taken from: https://www.ups.com/us/ en/services. page?WT.svl=Footer]. 
Table 7. Global logistic services of UPS

\begin{tabular}{|l|l|}
\hline Global activities & The most important provided services \\
\hline UPS Supply Chain Solutions & $\begin{array}{l}\text { Logistics and distribution; transportation and freight (air, sea, ground, rail); } \\
\text { freight forwarding to } 195 \text { countries; international trade management and } \\
\text { customs brokerage. }\end{array}$ \\
\hline Specialty services & $\begin{array}{l}\text { Service parts logistics; technical repair and configuration; supply chain design and } \\
\text { planning; returns management. }\end{array}$ \\
\hline UPS Freight & $\begin{array}{l}\text { Leading provider of less-than-truckload and truckload services coast-to-coast. } \\
\text { Delivery fleet - 5,629 vehicles and 21,282 trailers }\end{array}$ \\
\hline Freight Brokerage Services & $\begin{array}{l}\text { Coyote Logistics provides truckload, intermodal, and less-than- truckload } \\
\text { brokerage and transportation management services using a network of more } \\
\text { than 40,000 carriers across the United States, Mexico, and Canada. }\end{array}$ \\
\hline
\end{tabular}

Source: UPS, https://pressroom.ups.com/pressroom/ContentDetailsViewer.page? ConceptType =FactSheet\&id= 1426321563

187-193 (Date of access: June 18, 2017).

The tenth place was taken by DSV A/S company, which provides full warehousing and transport services (direct flights, road and sea connections). The company conducts the business activity in 80 countries and hires 40 thousand employees. It also operates in Poland. The company is currently flourishing on the Polish market, in terms of revenues from TFL's activity and in the development of convenient service offer as well as in the development of infrastructure, number of consignments and transports [DSV, Taken from: http://www.pl.dsv.com/About-DSV/media/News/2017/04/ Rekordowy-rok-DSV, (Date of access: June 19, 2017)]. There are three divisions of DSV Group: DSV Road (forwarding trade and land transport), DSV Air and Sea (air- and shipping forwarding), DSV Solutions (warehouse logistics). DSV A/S is the main copartnership of the entire organization.

\section{REFERENCES:}

1. A.P. Moller - Maersk, Retrieved June 14, 2017 from: http://www.maersk.com/en/the-maersk-group/about-us.

2. Baza aktów prawnych Unii Europejskiej, EUR-Lex, Retrieved from: http://eur-lex.europa.eu/legal-content/PL/ TXT/?uri=URISERV:I24456.

3. Biesok, G. (2013). Logistyka usług, CeDeWu, Warszawa.

4. CMA-CGM, Retrieved July 17, 2017 from: https://www.cma-cgm.com/the-group/about-us/corporate-movie.

5. DB Retrieved June 12, 2017 from: http://www.deutscheban.com/en/group/atglance/ facts_figures.html.

6. Demianiuk, R. (2015). Liderzy światowego i europejskiego rynku TSL, [w:] Матеріали Міжнародного наукового семінару «Транспортно-логістичний ринок України в контексті розширення співпраці з Євросоюзом». International Workshop "Transport and logistic market in Ukraine in the contex of increased cooperation with the EU», 19 Мау, 2015 - Луцьк: РВВ Луцького НТУ.

7. Demianiuk, R., Telakowiec, K. (2013), Oferta usługowa wiodq̨cych operatorów logistycznych polskiego rynku TSL, [w:] Demianiuk R. (red.), Marketing w działalności logistycznej, Wybrane przykłady, Uniwersytet Przyrodniczo-Humanistyczny, Siedlce.

8. DHL, Retrieved June 10, 2017 from: http://www.dhl.com/en/about_us/company_portrait.html.

9. DPD, Retrieved from: https://www.dpd.com.pl/klienci-biznesowi/O-DPD/O-firmie/Historia.

10. DSV, Retrieved June 19, 2017 from: http://www.pl.dsv.com/About- DSV/media/News/2017/04/Rekordowy-rok-DSV.

11. Fechner, I., Szyszka G. (red.) (2012). Logistyka w Polsce, Raport 2011, Biblioteka Logistyka, Poznań.

12. Fechner, I., Szyszka, G. (red.) (2014). Logistyka w Polsce, Raport 2013, Biblioteka Logistyka, Poznań.

13. Fechner, I., Szyszka, G. (red.) (2016). Logistyka w Polsce, Raport 2015, Biblioteka Logistyka, Poznań.

14. GLS Group, https://gls-group.eu/PL/pl/fakty-i-liczby\#.

15. Kuehne + Nagel, Retrieved June 14, 2017 from: https://www.kn-portal.com/about_us/about_us/.

16. La Poste, Retrieved June 16, 2017 from: http://legroupe.laposte.fr/profil/le-groupe-en-bref/I-essentiel.

17. Royal Mail, Retrieved June 17, 2017 from: http://www.royalmailgroup.com/about-us/who-we-are.

18. SNCF Group, http://www.sncf.com/en/meet-sncf/public-service-company.

19. Top 100 in European Transport and Logistic Services 2013/2014, http://www.scs.fraunhofer.de/content/dam/scs/de/ dokumente/studien/TOP100_Executive_Summary_20132014.pdf.

20. Top 100 in European Transport and Logistic Services 2015/2016, Fraunhofer Center for Applied Research on Supply Chain Services SCS, Nuremberg, https://www.scs.fraunhofer.de/content/dam/scs/de/dokumente/studien/Top 100 EU 2015 Executive Summary.pdf

21. UPS, Retrieved June 18, 2017 from: https://www.ups.com/pl/pl/about/facts/europe.page?. 


\section{IDENTIFICATION AND CHARACTERISTICS OF THE LEADERS OF THE EUROPEAN MARKET OF LOGISTIC SERVICES}

REGINA DEMIANIUK, PhD

https://doi.org/10.35945/gb.2017.03.007

Faculty of Economic and Legal Sciences,

Siedlce University of Natural Sciences and Humanities, Poland

KEYWORDS: LOGISTIC SERVICE, EUROPEAN TFL, SNCF

\section{SUMMARY}

Currently, logistic operators play a significant role in European economies and globally. They enable customers to find an offer which is suited to their individual needs and allow for optimization of their own supply chains.

In the article, the author attempts to identify the leaders of European logistic market as well as characterize service activities of selected leader companies. Contract logistics constitutes $41 \%$ of the European logistic market. Logistic operators are one of the largest companies of this sector in Europe and around the world. Protection of goods, safety of transport, on time deliveries and care of natural environment are priorities of the activity of TFL entities. Operators, leaders of the European logistic market have developed, dedicated and standardized network. Logistic operators constantly monitor processes in the supply chain and they are able to provide optimal solutions for logistic chains, taking into account needs and specification of each industry. The operators can provide many convenient solutions for their business partners by virtue of highly skilled employees, available infrastructure, processes and innovative systems implemented by the operators. 